\title{
Особенности коррекции психологического здоровья с помощью комплексной двухуровневой программы*
}

Важнейшими показателями, свидетельствующими о деформирующих изменениях в уровне здоровья, является: рост уровня тревожности и агрессивности, появление депрессивных состояний, падение самооценки, утрата необходимого уровня активности. Особенно это касается юношеского возраста.

Наше исследование посвящено выявлению показателей психологического здоровья в раннем юношеском возрасте, а также изучению эффективности комплексной программы, направленной на сохранение, поддержание и коррекцию психологического здоровья в юношеском возрасте.

Целью нашего исследования было изучить особенности нарушений психологического здоровья в раннем юношеском возрасте и разработать комплексную двухуровневую технологию, направленную на его сохранение, поддержание и коррекцию. Предметом исследования являлись общие и возрастные особенности психологического здоровья, специфичные для раннего юношеского возраста. Объектом исследования выступили юноши и девушки, обучающиеся в среднем профессиональном учебном заведении (медицинский колледж г. Ессентуки).

На предварительном этапе диагностического исследования выяснилось, что у основной массы студентов медицинского колледжа, отмечается высокий уровень агрессивности и тревожности, так же снижены такие показатели психологического здоровья, как самочувствие, активность, настроение и самооценка.

Достоверность и надежность полученных результатов обеспечивалась тщательной методологической проработкой понятий «психологическое здоровье личности», «возрастно-специфические показатели психологического здоровья», всесторонним анализом проблемы; использованием комплекса надежных и валидных методик, адекватных целям и задачам исследования, соблюдением норм

* Материалы представлены научным руководителем - зав.кафедрой психологии здоровья и физической культуры ЮФу, кандидатом биологических наук, профессором Васильевой O.C. 
и правил применения формирующего эксперимента; корректным применением методов математической статистики.

Выявленные показатели нарушений психологического здоровья, специфические для раннего юношеского возраста, позволяют адекватно и адресно выстраивать психолого-педагогическую помощь и поддержку юношам и девушкам с повышенным уровнем тревоги и агрессии.

Разработанная двухуровневая технология, была составлена в результате анализа большого количества исследований, посвященных коррекции физического и психологического здоровья. Предлагаемая технология состояла из четырех основных блоков: диагностического, установочного, коррекционного и блока оценки эффективности коррекционных воздействий. Изложена последовательность этапов работы группы (знакомство, формирование групповых норм, заключение договора об их соблюдении, сбор проблематики, рабочий этап) и организация данных этапов.

Для реализации спортивного блока комплексной коррекционной программы нами были выбраны занятия гидроаэробикой. Выбор гидроаэробики был соответствующим образом обоснован, в том числе, с опорой на научные исследования, посвященные сравнительному анализу эффективности занятий гидроаэробикой и занятий оздоровительным плаванием (О.Б. Галеева, О.Б. Звягина).

Была прописана цель оздоровительных занятий в воде, формы занятий, частота и длительность.

В формирующем эксперименте, направленном на поддержание и коррекцию психологического здоровья, принимало участие 200 человек. Диагностика всех испытуемых проводилась несколько раз. Данная выборка включала в себя 3 группы: контрольную (100 человек) и 2 экспериментальных (по 50 человек). В контрольную группу вошли испытуемые, с которыми не проводилась работа. В первую экспериментальную группу вошли испытуемые, занимающиеся только по психокоррекционной программе в течение 9 месяцев (в период с сентября 2004 года по май 2005 года); во вторую экспериментальную группу вошли испытуемые, прошедшие полный курс опытно-экспериментальной работы, согласно разработанной двухуровневой технологии. Все группы были однородны по полу и социальному положению.

Комплектование групп строилось с учетом следующих принципов: добровольность участия в программе; дифференцированный подход к участникам; конфиденциальность исследования; поэтапность и последовательность в реализации программы; целостность (комплексность) и относительная самостоятельность программы; информированность участников. Еще на этапе предварительных встреч со студентами приходилось сталкиваться с серьезным сопротивлением, незаинтересованностью в собственных изменениях, страхом работы с психологом.

На первом этапе исследования сравнивались результаты первого и второго замера, на втором этапе - показатели второго и третьего замеров. Показано, что сравнение показателей обоих этапов обнаружило статистически достоверные сдви- 
ги, позволяющие утверждать, что коррекционные воздействия явились значимыми только в том случае, когда испытуемые полностью были включены в эксперимент, состоящий из двух уровней коррекции. Результаты исследования показали, что в условиях отсутствия коррекционных воздействий, в течение длительного периода времени в показателях агрессивности и враждебности происходит (на статистически значимом уровне) сдвиг в сторону их увеличения. Таким образом, при отсутствии коррекционных воздействий, в условиях невмешательства, изменение показателей психологического здоровья имеет случайный, а, следовательно, неуправляемый характер. Сравнение показателей, полученных в первой экспериментальной группе при втором и третьем замерах, отражающих изменения в показателях исследуемых факторов, по результатам воздействия на испытуемых комплексной технологии, обнаружило, что произошел статистически значимый сдвиг в сторону улучшения показателей самочувствия, активности, настроения и адекватности самооценки и снижения уровня выраженности агрессивности и тревоги. Таким образом, комплексная двухуровневая технология, включающая спортивный и психологический блоки, оказывает существенное влияние на коррекцию показателей психологического здоровья в юношеском возрасте. Сравнение показателей, полученных во второй экспериментальной группе при втором и третьем замерах, отражающих изменения в выраженности исследуемых факторов, по результатам воздействия на испытуемых только психокоррекционных мероприятий, обнаружило, что сдвиг в сторону улучшения показателей самочувствия, активности, настроения и самооценки и снижения показателей агрессивности и тревоги не имеет значимых различий. Таким образом, использование только психокоррекционных мероприятий оказывается недостаточным для коррекции нарушений в психологическом здоровье, обусловленном возрастно-специфическими особенностями. В условиях применения разработанной комплексной двухуровневой технологии динамика показателей, свидетельствующих о нарушениях в психологическом здоровье, в том числе агрессивности, враждебности, тревожности, самооценки, самочувствия, активности, настроения приобрела прогнозируемый, управляемый, адаптивный характер. Дополнительный опрос студентов медицинского колледжа, принимавших участие в комплексной двухуровневой технологии, показал, что она оказала существенное влияние на развитие их личностного потенциала, что проявилось в улучшении отношений с родителями, друзьями, педагогами, в субъективном ощущении большей личностной зрелости.

\section{Литература}

1. Авворд М., Беккер П. Психокоррекционная работа с тревожными и дерпессивными детьми. М.: Апрель-Пресс. Эксмо-Пресс. 2000. 312 с.

2. Бэрон Р., Ричардсон Д. Агрессия. СПб.: Питер. 2003. 124 с.

3. Васильева О.С. Валеопсихологический подход к пониманию здоровья; //Психологический вестник РГУ.№5. 2000. С. 150 - 154. 